Dept. of Parasitology,

National Research Center, Dokki, Giza, Egypt.

\title{
STUDIES ON BLOOD PARASITES OF SHEEP AND GOATS AT QASSIM REGION, SAUDI ARABIA
}

(With 2 Tables)

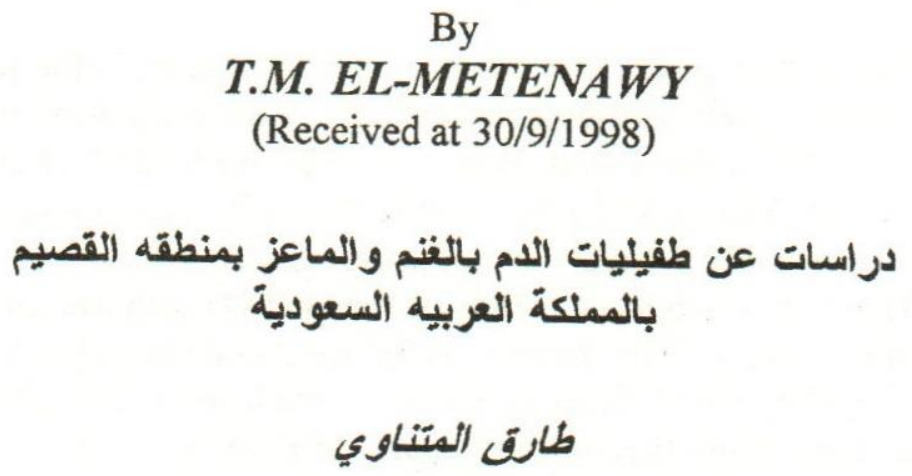

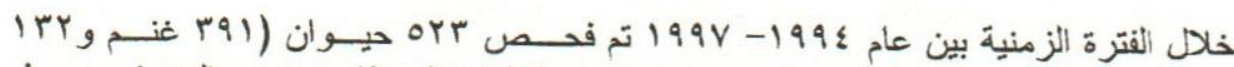

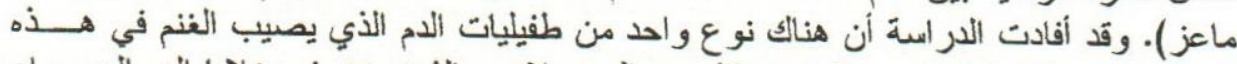

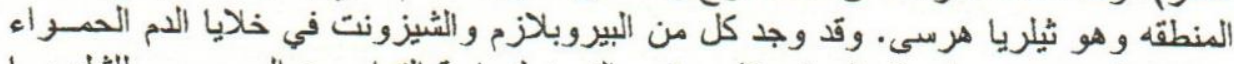

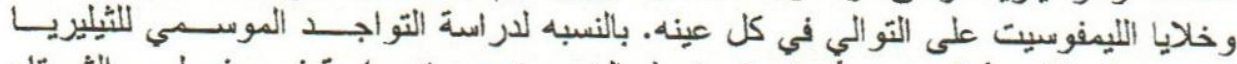

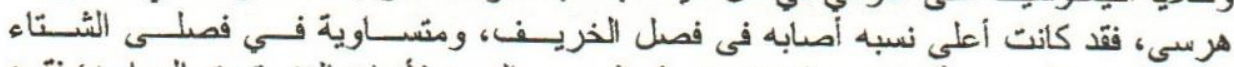

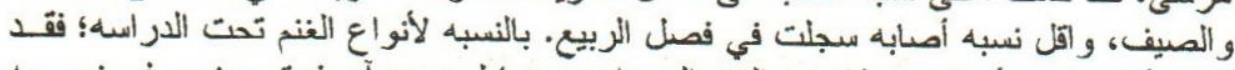

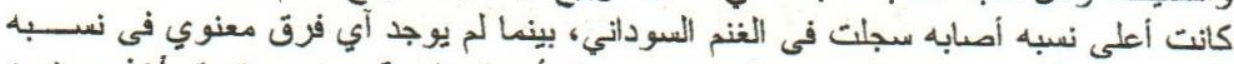

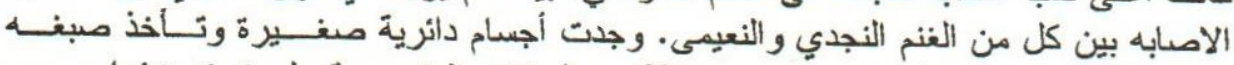

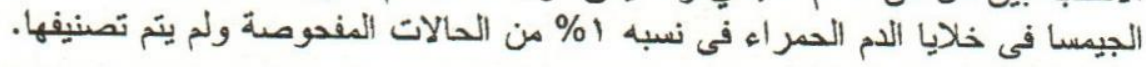

\section{SUMMARY}

Examination of 523 blood samples (391 sheep and 132 goats) collected from Qassim Region in a period from 1994 to 1997, revealed that Theileria hirci seems to be the only blood parasite infecting sheep and goats in this area. The overall infection percentage with that parasite among sheep and goats was $20.46 \%$ and $7.57 \%$ respectively. The parasite was mostly prevalent during the Autumn season, nearly equal in Winter and Summer seasons, while the infection with the parasite was minimum in the Spring season. The Sudanese sheep exhibit the highest 
infection rate with T.hirci, while there is no significance different in the infection rate between the Najdi and the Naeimi sheep. Small, round, basophilic granules in the RBCs were observed in $1 \%$ of the examined blood samples, it is not identified and it needs further investigations.

Key words: Blood Parasites,Theileria hirci, Sheep, and Goats,Al-Qassim, KSA.

\section{INTRODUCTION}

Sheep and goats are the main animal source in the Kingdom of Saudi Arabia. Their numbers according to the estimation of the Saudi Ministry of Agriculture and Water in 1988 are 6187747 sheep, and 3 486715 goats. Mutton and goat meat is the preferred meat in the country especially at Islamic festivals and other social occasions.

There are two main breeds of sheep at Qassim Region; the Najdi and Naeimi breeds. The former is the local and the oldest breed at AlQassim Region, while Naeimi sheep is the foreign and newly adapted breed brought from the northern part of KSA to Al-Qassim area. It is famous between Badweens and farmers that the Naeimi sheep is more resistant than the Najdi one in the Central Region.

The aim of this investigation is to study the prevalence and the seasonal incidence of the blood parasites affecting sheep and goats in the area. Also, to study the susceptibility of the two breeds of sheep against the natural infection with ovine and caprin blood parasites.

\section{MATERIAL and METHODS}

A survey on the blood parasites of sheep and goats was conducted in a period of 3 years (from 1994 to 1997). The samples were collected from 391 sheep and 132 goat. All the examined goats were local breeds, while the examined numbers of sheep were Najdi (149), Naeimi (103), Sudanese (26), and unidentified breed (113). All the animals were females and of various ages (one month to 5 years).

All the investigated animals were sick and brought to Al-Qassim Vet. Dig. Lab. Minist. Agric. at Bureidah province for the routine examination. The animals were brought in a recumbent state or freshly dead. Slides were directly prepared from the ear vein blood (thin and thick films), if the animal was living, and the impression smears were prepared from the prescapular lymph nodes, spleen, liver, kidney, and 
the heart blood of the examined animals after the PM (Kreier and Baker, 1987). The slides were left to dry, fixed in methanol and stained by freshly prepared Giemsa stain for $45 \mathrm{~min}$. (Levine, 1985). The observed parasites were identified according to the characters described by Levine, (1985); Brown, (1990); Kreier, (1994) and Soulsby, (1968).

\section{RESULTS}

During a survey in a period of 3 years, Theileria hirci was reported from (80) $20.46 \%$ out of 391 examined sheep and (10) $7.57 \%$ out of 132 goats. It has been found that the incidence of T.hirci among the two hosts was high during the Autumn season and the infection rate among sheep was double that of goats $(30.76 \%$ and $14.70 \%$ respectively). While the infection rate was nearly equal during the Winter and Summer season in the two hosts. Also, it has been found that the incidence of the parasite reach the minimum during the Spring season, where it was $5 \%$ in sheep and $0 \%$ in goats (Table 1 ).

In all the examined samples Koch's blue bodies were observed in the smears prepared from the prescapular lymph node and spleen. Also, the parasite was detected in the impression smears prepared from other organs (liver, kidney, lung, and the heart blood). Parasitized RBCs with the piroplasm sometimes were observed scattered in several internal organs.

Regarding to the susceptibility of the different breeds of sheep to the natural infection with T.hirci, it has been found that the incidence was higher in the Sudanese sheep than the other examined breeds (Table 2). Naeimi breed was found to be more susceptible to the infection than Najdi one, but the difference was not significant $(23.3 \%$ and $20.80 \%$ resp.)

In a low percentage $(1 \%)$ of the examined blood of sheep and goats, small, round, basophilic granules were observed in the erythrocytes. It was similar to the Anaplasma parasite. It was not identified and preserved for further studies.

\section{DISCUSSION}

During this study only T.hirci was clearly demonstrated in the blood and tissue smears of the infected sheep and goats. The incidence of the parasite in the present study was considered the second record 


\section{Assiut Vet. Med. J. Vol. 40 No. 79. October 1998.}

from the Kingdom, where Hussein et al (1991) was the first to record the parasite from native sheep and goats in Saudi Arabia.

It has been found that the overall infection percentage with T.hirci in the present study was $20.46 \%$ in sheep and $7.57 \%$ in goats. Hussein et al (1991) reported the incidence in goats, it was higher than reported from sheep at Qassim Region (13.3\% and 6.7\% resp). Moreover, the latter authors randomly examined small number of sheep and goats (15 for each) from Bureidah province and they don't mentioned the season of their study.

In the present study, T.ovis was not observed in the examined sheep and goats while it was recorded in the study of Hussein $\underline{\text { et }} \underline{\text { al }}$ (1991) with $20 \%$ infection rate in sheep and $40 \%$ in goats. Also, the parasite was recorded from Jeddah (Ghandour et al, 1989) with low incidence rate; and from eastern and northern region by Diab et al (1984).

T.ovis was not recorded in this study might be due to that the parasite was considered non pathogenic blood parasite for sheep and goats, and the animals submitted to this study were only sick and logically they were carried the pathogenic species which T.hirci.

During this study, it was noticed that $1 \%$ of the examined blood samples of sheep and goats had Anaplasma like bodies in the RBCs. In fact, it might be Rickettsia or Eperythrozoon. Specific identification is difficult on the basis of specimens seen in blood smears. Eperythrozoon ovis was previously recorded from sheep and goats in the kingdom by Diab et al, (1984) and Hussein et al, (1991).

\section{REFERENCES}

Brown C.G.D. (1990): Theileriosis. In Handbook on animal diseases in the Tropics, $4^{\text {th }}$-edn., eds. M.M.H. Sewell \& D.W. Brocklesby, pp. 183-199.

Diab, F.M.; Al-Asgah, N.A.; Al-Khalifa, M.S.; \& Hussein, H.S. (1984): Ticks and blood parasites from indigenous domesticated animals in Saudi Arabia. Seventh Symposium on the Biological Aspects of Saudi Arabia, Al-Qassim, SA, 20-22 March, programme \& Abstracts. 
Ghandour, A.M.; Tahir, M.O.; \& Shalaby, I.M. (1989): A comparative study of the prevalence of some parasites in animals slaughtered in Jeddah abattoir. Journal of King Abdulaziz University: Science, 1: 87-94.

Hussein, S.H.; Al-Asgah, N.A.; Al-Khalifa, M.S.; \& Diab, F.M. (1991): The blood parasites of indigenous livestock in Saudi Arabia. Arab Gulf J. Scient. Res.,9(3),pp. 143-160.

Kreier, J.P. (1994): Theileriosis. In Parasitic Protozoa, $2^{\text {nd }}$ ed., volume 7, Academic press, INC. A division of Harcourt Brace \& Company. Newyok, Boston, London.

Kreier, J.P. \& Baker, J.R. (1987): Parasitic Protozoa. Allen and Unwin. INC.,Bosto, London \& Sydney.

Levine, N.D. (1985): Veterinary protozoology. Iowa State University Press.Ames.

Soulsby, E.J.L. (1968): Helminthes, Arthropods, and Protozoa of Domesticated Animals Bailliere Tindall \& Cassell Ltd. London wc2.

Table (1): Seasonal incidence of T.hirci affecting sheep and goats at Qassim Region.

\begin{tabular}{|c|c|c|c|c|c|c|}
\hline \multirow{2}{*}{ SEASON } & \multicolumn{3}{|c|}{ SHEEP } & \multicolumn{3}{c|}{ GOATS } \\
\cline { 2 - 7 } & No. Exam. & +ve. No. & $\%$ & No. Exam. & +ve No. & $\%$ \\
\hline Winter & 105 & 21 & 20.00 & 46 & 3 & 6.52 \\
\hline Spring & 60 & 3 & 5.00 & 21 & 0.00 & 0.00 \\
\hline Summer & 122 & 24 & 19.67 & 31 & 2 & 6.45 \\
\hline Autumn & 104 & 32 & 30.76 & 34 & 5 & 14.70 \\
\hline Total & 391 & 80 & 20.46 & 132 & 10 & 7.57 \\
\hline
\end{tabular}

Table (2): Incidence of T.hirci among different breeds of sheep at Qassim region.

\begin{tabular}{|l|c|c|c|}
\hline BREED & No. Exam. & +ve No. & $\%$ \\
\hline Najdi sheep & 149 & 31 & 20.80 \\
\hline Naeimi sheep & 103 & 24 & 23.30 \\
\hline Sudanese sheep & 26 & 8 & 30.76 \\
\hline Unidentified sheep & 113 & 17 & 15.04 \\
\hline Total & 391 & 80 & 20.46 \\
\hline Goats & 132 & 10 & 7.57 \\
\hline
\end{tabular}


